\title{
О ПЕРСПЕКТИВНОСТИ КРАШЕНИЯ ТЕКСТИЛЬНЫХ МАТЕРИАЛОВ ПРИРОДНЫМИ КРАСИТЕЛЯМИ
}

\author{
Яминзода (Яминова) 3.А.
}

к.т.н., доцент

Икрами М.Б.

к.х.н., доцент

Олимбойзода П.А.

аспирант

Технологический университет Таджикистана

Аннотация: В статье рассмотрены экологические проблемы отделочного производства текстильной промышленности. Показана экологическая безопасность природных красителей и перспективы их применения в колорировании текстильных материалов.

Ключевые слова: текстильная промышленность, синтетические и природные красители, экологическая безопасность.

Несколько тысячелетий человечество использовало для крашения текстиля, кожи и других объектов материальной культуры природные красители. Открытие синтетических красителей и развитие их промышленного производства свело на нет использование природных красителей и привело к практической утере технологий крашения ими. В современной текстильной промышленности применяются десятки тысяч синтетических красителей и их число с каждым годом возрастает. Несомненно, синтетические красители обладают рядом преимуществ по сравнению с природными аналогами. Они более технологичны, позволяют получать большое число стойких, ярких, чистых цветов и оттенков, более дешевы. Однако они создают серьёзные экологические проблемы, которые стали очевидны в середине 20 -го столетия и в настоящее время становятся все более очевидными. Как указывается во многих научных работах, текстильная промышленность, а именно отделочное производство, относится к отраслям, наносящим наибольший урон окружающей среде [1-3]. Сточные воды отделочного производства содержат остаточные количества красителей, содержащих чаще всего наиболее опасные хромофорные системы с различным строением: азо-, металлокомплексные, прямые, сернистые, оксидационные, которые являются канцерогенами, 
вызывают поражение желчного пузыря, печени, почек и др. Кроме указанных красителей сточные воды отделочного производства содержат технологические вспомогательные вещества, применяемые для предварительной и заключительной отделки, такие, как кислоты, щелочи, мягчители и т.д. В целом, существует более семи тысяч разрешенных к использованию и применяемых в текстильной промышленности вспомогательных веществ. Из данных, приводимых во многих научных источниках, «из общего количества органических химических продуктов, которые сейчас расходуются в мире (порядка 250 млн. тонн) и часть которых бесконтрольно попадает в окружающую среду, значительная доля приходится на химико-текстильные технологии» [4].

Токсичные химические вещества, попадая в окружающую среду не только к приводят к изменению ее качества, но и поступают в живые организмы и участвуют в процессах обмена веществ, становясь причиной негативных последствий и различных заболеваний .

Как считает профессор Г.Е. Кричевский [5], уменьшение экологической нагрузки на окружающую среду может быть достигнуто прежде всего за счет исключения или резкого снижения сброса вредных веществ в сточные воды и их выброса в атмосферу. Для успешного решения этих проблем необходима разработка специальных эко-технологий отделки текстиля, обеспечивающих создание нетоксичных текстильных материалов, соответствующих требованиям специальных стандартов. Как правило, эко-технологии характеризуются минимальным ресурсопотреблением (вода, тепло, электроэнергия). Одним из видов этого направления может быть разработка технологий крашения текстильных материалов природными красителями, получаемыми из растительного сырья.

В настоящее время проблема колорирования текстильных материалов натуральными красителями растительного и животного происхождения вызывает повышенный интерес во всем мире. Этот интерес обусловлен многими причинами и прежде всего их экологичностью [5].

Известно, что синтетические красители часто проявляют токсические и канцерогенные свойства, становятся причиной возникновения аллергических реакций, болезней дыхательных путей и т.д. Но экологические проблемы, создаваемые ими, не ограничиваются только этим. При промышленном крупнотоннажных производствах накапливаются огромные количества отходов, многие из которых опасны для окружающей среды и здоровья 
человека; их утилизация становится все более серьезной проблемой и требует больших материальных затрат. Промышленное производство синтетических красителей требует значительных сырьевых ресурсов, наличия квалифицированных кадров, транспортную и социальную инфраструктуру, требует огромных расходов. Организация индустриального производства нецелесообразна в местах, не отвечающих этим условиям.

Производство природных красителей из сырья на их основе имеет весьма благоприятные показатели, связанные с отходами: число отходов производства красителей невелико - это вода, растворы обычных солей и сухие остатки растительного или животного сырья. Отходы этого производства, так же как и сами красители, - экологически чистые продукты, которые легко утилизировать в полезные продукты.

Материальные объекты, в том числе текстильные изделия, окрашенные красителями, контактируют непосредственно с человеческим телом. Эти вещества, тем или иным способом контактирующих с организмом человека, помимо наличия соответствующих цветовых характеристик, должны удовлетворять очень жестким экологическим условиям. Они должны обладать следующими медицинскими показаниями: не вызывать пищевых и кожных отравлений; не давать аллергических эффектов; не оказывать канцерогенного действия. Причем отрицательные эффекты воздействия на человеческий организм должны отсутствовать у хромогенов как в краткосрочной, так и долгосрочной перспективе [6]. Особенно важно отсутствие негативных воздействий при длительном применении указанных веществ.

Степень чужеродности человеческому организму синтетических красителей не сравнима с природными аналогами. По химическому строению молекул большинство синтетических красителей существенно отличается от естественных биомолекул, из которых строится организм живых существ. Поэтому многие синтетические красители не удовлетворяют вышеперечисленным экологическим требованиям и даже оказывают патогенное воздействие на человеческий организм. Природные красители же по химическому строению близки к естественным биомолекулам человеческого организма. Помимо этого, следует учитывать, что «природные органические вещества растительного и животного происхождения, содержащие природные органические хромогены, в течение длительного времени употреблялись в качестве пищи; некоторые природные хромогены (например, куркума, шафран) с давних пор применялись для окраски пищевых продуктов и в качестве 
пряностей; некоторые природные хромогены издавна использовались в косметике (например, лак-дэй, шиконин, красители кермеса, кошенили, хны и басмы)» [6]. В ходе эволюции человек адаптировался к воздействию указанных веществ. Поэтому, в отличие от синтетических, природные органические красящие вещества не выявили отрицательных последствий контакта с человеческим организмом. Из этого следует, что природные красители значительно лучше удовлетворяют вышеназванным экологическим требованиям и обладают существенными экологическими преимуществами перед их синтетическими аналогами.

Одной их причин, обуславливающий возрождения интереса к природным красителям является возобновляемость источников сырья для их получения и истощение ресурсов углеводородов, из которых получают синтетические красители. В большинстве своем природные красители относятся к веществам растительного происхождения, и их можно получить из дешевого и доступного сырья или из отходов производства деревообрабатывающей, а также фармацевтической отраслей промышленности [5].

Достоинством природных красителей считается гармоничность цветов, высокая устойчивость окраски, о чем свидетельствуют музейные текстильные материалы и ткани, найденные при археологических раскопках. Технологические свойства указанных красителей можно изменить или улучшить с помощью их модификации, что является предметом исследований многих ученых [7, 8].

Следует отметить, что природные красители представляют собой не индивидуальное вещество, а смесь природных веществ, часто обладающих биологической активностью, антисептическими, противомикробными свойствами. В связи с чем, текстильные материалы, окрашенные ими, будут устойчивы к микробиологической порче, возможно, будут обладать некоторыми защитными и лечебными свойствами.

Таким образом, вышесказанное позволяет сделать вывод, что применение природных растительных красителей имеет хорошие перспективы для создания экологически безопасных технологий отделки текстильных материалов и других предметов потребления.

Наличие у природных красителей ряда преимуществ по сравнению с синтетическими красителями, которые особенно важны в свете появления экологических проблем, а также значительные ресурсы дикорастущего сырья и возможность его сельскохозяйственной переработки определяют 
целесообразность разработки технологий получения и применения природных красителей как в легкой, так и в пищевой промышленности. Эта проблема важна и актуальна и для нашей республики, которая, не имеет возможности для развития крупнотоннажного промышленного производства синтетических красителей, которые в настоящее время достаточно дороги, и в том же время обладает значительными ресурсами красильных растений. Применение природных растительных красителей оптимально также для развития народные традиционные производств.

Очевидно, что создавать крупное производство природных красителей экономически невыгодно. Однако благодаря экологической чистоте и безопасности, а также наличию полезных биологически активных свойств природные красители целесообразно применять в таких производственных областях, где важна максимальная экологическая чистота материалов - в производстве одежды для больных, особенно с повышенной аллергической чувствительностью, в производстве одежды, обуви и других предметов для детей, включая детские игрушки.

Как отмечают специалисты, для производства природных красителей целесообразно и выгодно создавать малые предприятия [6]. Малые производства не требуют значительных затрат для их создания, а также сложного и дорогостоящего оборудования и высококвалифицированных кадров. Создание таких производств особенно важно там, где наиболее развита традиционная национальная культура. Такие производства могли бы производить высокохудожественные изделия, которые, с одной стороны, способствовали бы сохранению традиционной культуры.

\section{Список литературы}

1. Ковтун, Л.Г. Применение природных красителей для колорирования текстильных материалов / Л.Г. Ковтун, Е.Л. Маланкина // Текстильная химия. - 1999. - №1 (16). - С. 69 - 74.

2. Шагина Н.А. Разработка экологичной технологии использования природных красителей растительного происхождения в колорировании текстиля. Дисс. к.т.н., М., 2015,134 с.

3. Тасымбекова А.Н., Логинова Л.В., Нурмаханкызы Н. Крашение шерстяных материалов природными красителями. Технология текстильной промышленности, 2018, №5 (377), с.120-124 
4. Киселёв А.М. Экологические аспекты процессов отделки текстильных материалов // Рос. хим. ж. (Ж. Рос. хим. об-ва им. Д.И. Менделеева), 2002, т. XLVI, № 1c.20-30

5. Ковтун Е.Г., Маланкина Е.Л., Артамонцева Л.В., Люлько Н.И. Влияние процесса крашения шерсти природными красителями на раствормость шерстяного волокна в мочевино-гидросульфитном и щелочном растворах. // Технология текстльной промышленности, 2007, № 3 (298) с.67-69

6. Голиков В. П. Органические хроматические материалы на основе природных красителей в произведениях искусства: природа, технологии приготовления и применения, методы исследования. - М. : Институт Наследия, 2020. - 296 с. -

7. Неборако О.Ю. Химическая модификация и исследование свойств природных красителей растительного происхождения: дисс. канд. хим.наук: 02.00.03. М., 2005. 120 c.

8. Кобраков К.И., Кузнецов Д.Н., Ручкина А.Г., Надырбаев И.А., Кляузова А.В. Синтез и исследование свойств азокрасителей и азопигментов на основе полифенолов различного генезиса. // НефтеГазоХимия, №1, 2018, c. $25-28$ 